\title{
Waterbirds and human-related threats to their conservation in Laguna Cuyutlán, Colima, México
}

\section{Eric Mellink ${ }^{1}$ \& Mónica Riojas-López ${ }^{2}$}

1. Departamento de Biología de la Conservación, Centro de Investigación Científica y de Educación Superior de Ensenada, Baja California, carretera Tijuana-Ensenada, Km. 107, Ensenada, B.C., México; emellink@cicese.mx

2. Departamento de Ecología, Centro Universitario de Ciencias Biológicas y Agropecuarias, Universidad de Guadalajara, Km 15.5 carretera a Nogales, 45100 Zapopan, Jalisco; meriojas@cucba.udg.mx

\section{Received 11-II-2008. Corrected 30-VI-2008. Accepted 31-VII-2008.}

\begin{abstract}
Laguna Cuyutlán, the only large wetland in a span of $1150 \mathrm{~km}$ along the Pacific coast of México, has been neglected as to its importance for waterbird conservation. At least 25 waterbird species nest there, with some of their colonies being very relevant, and at least 61 waterbird species use the lagoon during their nonbreeding season. This lagoon has been subject to several structural modifications, including levees and artificial channels which connect it to the sea, while water supply from continental sources has diminished, although its role has not been assessed yet. Salt extraction and artisanal fishery, the main economic activities, do not seem to pose a threat to waterbirds. Among potential threats to this acquatic ecosystem, are the raw sewage discharges that exist near urban areas, and pesticides from the surrounding agricultural lands might reach the lagoon. Seemingly, the most serious threat comes from waterway development in connection with a re-gasification plant to be built, and planned future port expansion, which could potentially increase water levels and alter important habitats for nesting and foraging. We recommend that: the area be declared an Important Bird Area; the development of the re-gasification plant and future port includes a levee to prevent alterations in water level in the remaining sections of the lagoon; supply of exogenous chemicals and waste products be prevented and monitored; alleged benefits from water interchange between the lagoon and the sea through artificial channels should be re-evaluated; and the role of fresh water supplies to the lagoon should be paid attention to. Rev. Biol. Trop. 57 (1-2): 1-12. Epub 2009 June 30.
\end{abstract}

Key words: Laguna Cuyutlán, Colima, México, waterbirds, conservation biology, port development, fresh water supply.

\footnotetext{
"This portion of the tierra caliente and the Laguna de Cuyutlán is a most fertile field for ornithological research..."

Geiger, 1874
}

Geiger's (1874) remark did not stimulate ornithologists, and we still know little about the history of the waterbirds of Laguna Cuyutlán, Colima, and the factors that have influenced it. However, along the Pacific coast of Mexico, this is the only large coastal wetland between Marismas Nacionales, Nayarit and the center of the state of Guerrero, roughly $1150 \mathrm{~km}$. The importance of this lagoon, along with that of nearby wetlands, has been neglected for the observation (Howell 1999) and conservation of birds (see Arizmendi and Márquez-Valdelamar 2000), perhaps largely because of paucity of data. Laguna Cuyutlán has been neglected also in other conservation oriented schemes. For example, the lagoon is within the "Purificación and Armería Rivers Priority Watershed," of Mexico's National Commission for the Study 
and Conservation of Biodiversity (CONABIO), but it is barely mentioned in the technical fact sheet, which includes no waterbirds at all. Likewise, the lagoon is part of CONABIO's "Cuyutlán-Chupadero Priority Marine Region," but is specifically excluded from the sites therein proposed for conservation as it is "highly exploited by industry," according to the fact sheet. The closest waterbird AICA ("Area de Importancia para la Conservación de las Aves," equivalent to the "Important Bird Areas" in other countries) is Marismas Nacionales, over $300 \mathrm{~km}$ to the northwest (Arizmendi and Márquez-Valdelamar 2000).

Despite such neglect, this lagoon could play an important role in waterbird conservation (Knoder et al. 1980, Mellink and de la Riva 2005, Mellink and Riojas-López 2005, 2006, 2008, Mellink et al. 2007, Palacios and Mellink 2007). In this essay we intend to: 1) assess the conservation value of Laguna Cuyutlán for waterbirds, 2) review the potential threats for the waterbirds that use Laguna Cuyutlán and, 3) propose some basic management actions that might help to reduce the consequences of human activities and to conserve the role of Laguna Cuyutlán in the conservation of waterbirds. We do not include other nearby wetlands, like Laguna San Pedrito, as they are already being filled in and transformed for industrial needs.

This essay derived from our own research from 2003 to 2007. We also thoroughly reviewed all information available. Formally published information about the lagoon is scant, and some valuable information is available only in the "gray" literature. We reviewed all such literature, but included here only those sources that were relevant to our objectives. Finally, we interviewed persons who could improve our perception of the lagoon's conservation problems. They are acknowledged where appropriate.

\section{LAGUNA CUYUTLÁN: THE GEOGRAPHIC SETTING}

Laguna de Cuyutlán (1856' - 1903'N, $104^{\circ} 00^{\prime}-104^{\circ} 19^{\prime} \mathrm{W}$ ) covers 7200 ha and is
$35 \mathrm{~km}$ long, and $6 \mathrm{~km}$ at it widest (Contreras 1985; Fig. 1). Depth diminishes from northwestern to southeastern, where it is less than $1 \mathrm{~m}$. The Lagoon has been divided into four basins (Fig. 1). Basin I, the deepest of the lagoon (maximum depth $=4.4 . \mathrm{m}$ ) is a small section at the northwestern end of the lagoon, separated by a levee built in 1889 to support the railroad track to the port of Manzanillo, and connected to the sea through artificial Canal Ventanas (the history of hydrological modifications of the lagoon is summarized by Mellink and Riojas-López 2007). It currently harbors a thermoelectric plant. Basin II is the area between the former and a natural mountainous constriction to the southeast. It reaches depths of $1 \mathrm{~m}$, and is connected to the sea through a tunnel and Canal Tepalcates, both artificial. This basin includes two large islands. Basin III is the area between the latter constriction and a section of shallows further southeast. It is 0.20 $\mathrm{m}$ deep, and has no direct connections with the sea. This basin includes two small islands, and many small, low islets which are uncovered at certain low water levels. Basin IV is the area between previous shallows and the end of the lagoon. Its depth is sometimes only $0.20 \mathrm{~m}$. It is not connected with the sea, but is connected to a small coastal lagoon, Estero Palo Verde.

The climate is tropical, with a mean annual temperature of $26^{\circ} \mathrm{C}$ (range: 22.4 - 29.7), mean annual precipitation of $975.2 \mathrm{~mm} \mathrm{(625.5-1}$ 341.3), and mean air humidity of 73.6 (68.4 -75.8; Mena-Herrera 1979). Vegetation along the shores of the lagoon is mostly of mangroves (Rhizophora mangle and Laguncularia racemosa) and tule (Typha domingensis), while beachwort (Batis maritima), saltgrass (Distichlis spicata) and saltbush (Atriplex spp.) occur at the edge and on shallows within it. Aquatic vegetation includes widgeongrass (Ruppia maritima), muskgrass (Chara sp.), bulrush (Scirpus spp.), spikerush (Eleocharis sp.), glasswort (Salicornia sp.), grasses (Fam. Poaceae), and duckweed (Fam. Lemnaceae) (Saunders and Saunders 1981). Aquatic vegetation seems to vary in response to changes in water salinity. For example, in March 1960, 


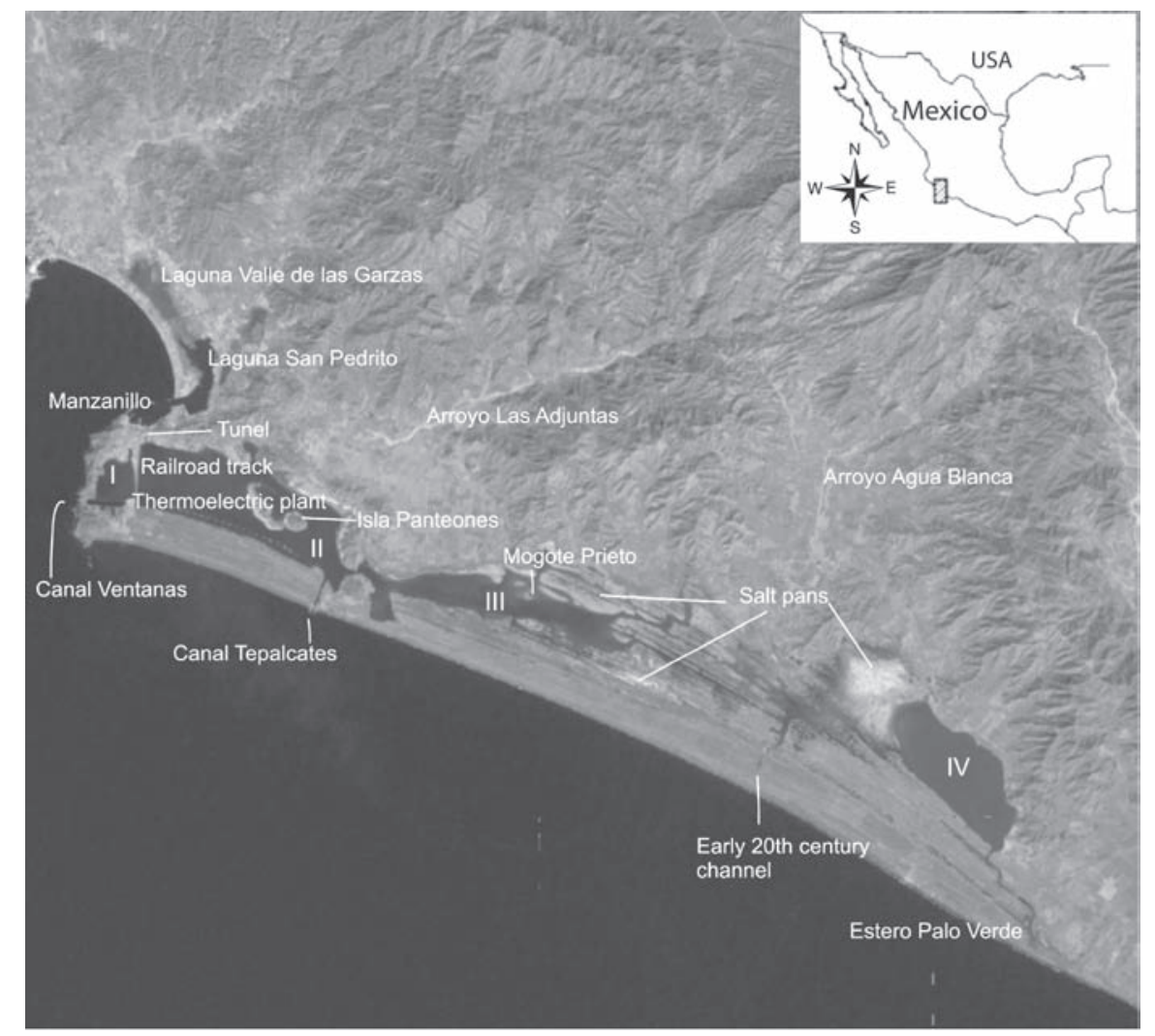

Fig. 1. Laguna Cuyutlán, Colima, México. I, II, III, and IV indicate the four basins of the lagoon.

anomalously, the only submerged aquatic vegetation were algae, a fact attributed by fishermen to a recent lack of fresh water (Saunders and Saunders 1981). Away from the lagoon, the low hills that have been spared from agriculture are covered with tropical deciduous forests.

\section{IMPORTANCE OF LAGUNA CUYUTLÁN FOR WATERBIRDS}

In a few pre-2000 surveys during the waterbird breeding season, Laguna Cuyutlán was documented as holding large colonies of some waterbirds: In 1959 (Schaldach 1963), one of the islands in basin II supported nesting of "hundreds" of neotropic cormorants (Phalacrocorax brasilianus), 100+ little blue egrets (Egretta caerulea), 100+ great egrets
(Ardea alba), some snowy egrets (E. thula), and the apparent nesting of some tricolored herons (E. tricolor). Aerial surveys in 1977 and 1978 (Knoder et al. 1980) revealed 30 nests of great egret, 8000 nests of [neotropic] cormorants, the nesting of 10000 laughing gulls (Larus atricilla), and that of [magnificent] frigatebirds (Fregata magnificens, number not stated). Howell and Webb (1995) added clapper rail (Rallus longirostris, although it could be rather the king rail, $R$. elegans; see Howell 1994) and black skimmer (Rynchops niger) to the list of breeders. Recently, we documented the nesting of neotropic cormorant, tricolored egret, snowy egret, little blue heron, great egret, cattle egret (Bubulcus ibis), blackcrowned night-heron (Nycticorax nycticorax), yellow-crowned night-heron (Nyctanassa 
violacea), green heron (Butorides virescens), roseate spoonbill (Platalea ajaja), white ibis (Eudocymus albus), black-bellied whistlingduck (Dendrocygna autumnalis), snowy plovers (Charadrius alexandrinus), Wilson's plovers (C. wilsonia), black-necked stilt (Himantopus mexicanus), royal terns (Thalasseus maximus), least terns (Sternula antillarum), gull-billed terns (Gelochelidon nilotica), Forster's terns (S. forsteri), black skimmer and laughing gulls (Mellink and Riojas-López 2005, 2006, 2008, unpub. data; Mellink et al. 2007; Palacios and Mellink 2007). The list of breeders is increased by species nesting elsewhere in the lagoon, but for which no data have been published. For example, the boat-billed heron (Cochlearius cochlearius) and brown pelican (Pelecanus occidentalis) nest in the Basin IV - Estero Palo Verde area (M.C. Rivera pers. comm.). Only the clapper rail and least tern are included in Mexico's official list of protected species, albeit in the lowest category ("special protection").

Some of these waterbird colonies are highly relevant. In 2005 the entire breeding population of the vanRossem's gull-billed tern ( $G$. n. vanrossemi) was estimated at 526 breeding pairs, which nested at only 13 sites in western Mexico and southwestern United States (Palacios and Mellink 2007; one colony further southeast added recently; Mellink et al. accepted-a). The local colony of Forster's Terns represents a leap of $1,730 \mathrm{~km}$ from the nearest Pacific Coast colony (Mellink and Riojas-López 2006). Although summing up to thousands of pairs in western North America, Laughing Gulls nest at only a few locations, one of which is Laguna Cuyutlán. Based on aerial surveys during the breeding season, Knoder et al. (1980) considered Cuyutlán one of the 19 most valuable waterbird habitats in western Mexico.

Six habitats are used for nesting in Laguna Cuyutlán: Mangroves on larger islands (pelecaniformes and ciconiiformes); mangrove shrubs on islets (green heron); low islets in shallow water (black-necked stilt, laughing gull, royal tern, gull-billed tern, Forster's tern, and black skimmer); marsh (clapper rail); saltflats (snowy and Wilson's plovers and least tern); and patches of tropical deciduous forest (neotropic cormorant, black-bellied whistling-duck).

Between September 1996 and March 1997 at least 57 species of waterbirds used the lagoon during the non-breeding season, although only 11 species provided $90 \%$ of all individuals (Mellink and de la Riva 2005). Four species were added in January 2008 (Mellink et al. accepted-b). Laguna Cuyutlán was especially important for american white pelican (Pelecanus erythrorhynchus), ruddy duck (Oxyura jamaicensis), green-winged teal (Anas crecca), and western sandpiper (Calidris mauri), which used the lagoon as a stopover site. Other coastal habitats along the mid-western coast of Mexico are much smaller and are used by different species. For example, the relatively nearby coastal lagoons of Majahuas and El Chorro, Jalisco, $\left(19^{\circ} 52^{\prime} \mathrm{N}\right.$ and $\left.105^{\circ} 23^{\prime} \mathrm{W}\right)$ are used essentially by common terns ( $S$. hirundo, Hernández-Vázquez and Mellink 2001).

The southern part of Mexico's Pacific coast supports less than $5 \%$ of the waterfowl wintering along the western coast of Mexico (Kramer and Migoya 1989), and no coastal lagoon appears as important (Pérez-Arteaga et al. 2002). Although modest in this context, within the southern Pacific Mexican coast, Laguna Cuyutlán was the most important waterfowl site (Leopold's 1977). In a 1947 winter aerial census, 177435 ducks were counted, including 46200 lesser scaups (Aythya affinis), 41900 gadwalls (Anas strepera), and several thousand black-bellied whistling ducks (Saunders and Saunders 1981). However, waterfowl abundance plummeted in 1955, at Laguna Cuyutlán, but not at other estuarine systems in southern Mexico. The species involved did not exhibit range-wide population reductions, and this reduction was caused, in all likelihood, by the derivation of most fresh water from the Ayuquila-Armería watershed to human uses, mostly agriculture, causing the loss or deterioration of ecological processes (Mellink et al. accepted-b).

In February 1994, Laguna Cuyutlán along with the Manzanillo wetlands, was the second 
most important site for shorebirds in the southern Mexican Pacific coast, with 15371 small, 3738 mid-sized, and 22920 large shorebirds, and had the largest number of black-necked stilts (12 127) anywhere along western Mexico (Morrison et al. 1992, 1994). Many of the black-necked stilts breed there. No data exist to evaluate year-to-year variations in shorebirds and seabirds using Laguna Cuyutlán during the non-breeding season.

Clearly, Laguna Cuyutlán is important for waterbird conservation, both as a breeding locale as well as migratory stopover or wintering place. At least 25 species of waterbirds have been confirmed to nest in Laguna Cuyutlán, and at least 61 species have been recorded to use the area during the non-breeding season. The breeding species include, rather anomalously, Forster's tern, while the colonies of gull-billed terns, royal terns, black skimmers, and snowy plovers are relevant for the conservation of these species, as are the very large numbers of resident laughing gulls and, to a lesser degree, black-necked stilts. The breeding of these species depends on water levels being low enough to uncover small, low, muddy islets during the Spring.

Laguna Cuyutlán is possibly a critical shorttime stopover site for some bird species (sensu Myers 1983, and Myers et al. 1987), and an alternative wintering habitat for others. Although yearly variations in the value of Laguna Cuyutlán during the non-breeding season remain unstudied, they also seem to depend on water levels. On their part, waders (Ciconiiformes) use the shallow parts of the lagoon extensively to forage, both during the non-breeding and breeding season (Mellink and de la Riva 2005, Mellink and Riojas-López 2008).

\section{HUMAN USE OF THE LAGOON, AND POTENTIAL IMPACTS TO THE BIRDS}

Laguna Cuyutlán has been long famed for its salt for human consumption, and salt has been extracted at the edges of the lagoon uninterruptedly since Prehispanic times (Anonymous 1850, Pérez Ponce de León 1979,
Ewald 1985, Marmolejo-Rodríguez 1989). Salt is produced along some shores of Basin III and between Basins III and IV, and depends on low water levels in Winter and Spring. It usually begins in January, with the building of the salt pans, and ends in June, with their inundation by rising water levels due to the onset of the rainy season. In some years, water supplies to the lagoon are scant and the water level in the lagoon is unusually low, allowing for a start as early as December, as in late 2005 (J.L. Ramírez, Jesús Delgado-Virgen, and Telésforo Ramírez-Montes pers. comm.). In contrast, high Winter water levels can reduce substantially the area devoted to salt pans, as occurred in 1909 and 1911, while the early onset of the rainy season, as happened in 1978, severely impacts salt production (Ewald 1985). Currently, over 2 000 ha are devoted to the cooperative artisanal production of salt. Yearly production of salt varies. It was reported to be 17876 metric tons in the 1970s (Mena-Herrera 1979), but in 2005 was said to be around $104000 \mathrm{mt}$ (J. DelgadoVirgen and T. Ramírez-Montes pers. comm.). About 2000 families are seasonally dependent on this activity, not counting truck drivers and other workers involved after the salt leaves the Cuyutlán area.

Laguna Cuyutlán is not used for recreational fishing and boating, but is used for local, artisanal fishing. Thirty-one species of fish have been recorded from the lagoon (Cabral-Solis and Espino-Barr 2004), but fishing is focused on shrimp (mostly brown shrimp (Farfantepenaeus californiensis, $150 \mathrm{mt} / \mathrm{yr}$ ), mojarras (Gerreidae, 104 metric ton/year), mullets (Mugilidae, up to $100 \mathrm{mt} / \mathrm{yr}$ ), sea catfishes (Ariidae, $52 \mathrm{mt} / \mathrm{yr}$ ), and crabs (Callinectes sp.), although other fishes are also taken (MenaHerrera 1979; Ascencio-Borondón et al. 1987, Cabral-Solis 1999).

Between 2000 and 2004 total fish catches diminished from 132 metric ton to 53 m.t. and from 770 to $372 \mathrm{~kg} /$ fisherman/year (CabralSolis et al. 2006b). Reduced water interchange between the lagoon and the sea has long been a favorite culprit to blame for low or decreasing catches of fish and shrimp inside 
the lagoon (for example, Mena 1979, and Ascencio-Borodón et al. 1987), and the very low shrimp catch of the 2005-2006 season was attributed to unusually low water levels resulting from little rain and, allegedly, the closure of Canal Tepalcates (J.L. Ramírez pers. comm.). Also, a large fish die-off in 2005 was attributed to reduced oxygen levels in the lagoon, as a consequence of a lack of oceanic connection. In response to such claims, Canal Tepalcates was opened in 2000. Fish diversity values increased in the immediate vicinity of the channel after it was opened (Cabral-Solis et al. 2006a), but nothing has been reported on the mid-term effects of the lagoon's artificial openings. Some fishermen believe that fish populations actually decreased and impoverished after the opening of Canal Ventanas, and that opening Canal Tepalcates did not improve fishing conditions (Jorge Aguilar-Torres, pers. com.). Internal dredging has also been proposed to increase water flow and, allegedly, shrimp production (Mena 1979).

In contrast, the effects of reduced supply of fresh water through the Río Armería and, perhaps, local seeps, which was indicated in 1950 by local fishermen as influencing fish and shrimp abundance in the lagoon (Saunders and Saunders 1981), has not been investigated (Mellink et al. accepted-b). One fishermen reported that after the opening of Canal Ventanas, a thin-shelled clam dissapeared (Jorge Aguilar-Torres, pers. com.). This could have been an Anodonta sp., and its disappearance a result of the combined effects of reduced freshwater supplies and saltwater entrance. The almost disappearance of waterfowl from the lagoon has been linked to such a reduction in freshwater (Mellink et al. accepted-b).

Aquaculture has been proposed as a solution for socio-economic needs along the coasts of southern Mexico (Jiménez 1992), and most fishermen in Laguna Cuyutlán welcomed the idea of practicing some form of aquaculture (Hugues-Dit-Ciles 2000). However, when governmentally supported opportunities to establish aquaculture farms arose several years ago, local inhabitants did not take advantage (J.L.
Ramírez pers. comm.). Until mid 2006 a tilapia (Oreochromis niloticus) farm existed at the side of the lagoon. Although this species has potential negative impacts if released into natural systems (Canonico et al. 2005), fishing authorities in Mexico support its production. At the end of 2006 this aquaculture facility was not operating, apparently because it was flooded by the heavy rains of that year. Whether this caused a release of tilapias into the lagoon was unknown.

There are no records of current regular hunting of waterbirds or egg gathering for human consumption, or for any other purpose. However, given the large numbers of Laughing Gulls breeding at Cuyutlán, the relatively easy access to them, the size of the eggs, some temporal coincidence with salt extraction, and the poverty of many salt workers, it seems possible that such use actually happens. On the other hand, mangrove branches are probably used at small scale for firewood, but we have not seen any deforested mangrove patches away from habitation areas. If at all, these two activities occur at levels so low that they are probably not of conservation concern.

Except for the area which is occupied by human settlements or is hilly, the native tropical forests which covered the area around the lagoon, including the sandbar that separates it from the sea (see photographs in Sosa 1939), have been converted to agriculture. Local agriculture is based mostly on the production of limes and coconuts, but other crops are also grown (INEGI 1996). As part of the farming practices, worldwide used fungicides (mancozeb, benlate, captafol, copper compounds), insecticides (methamidophos, dimethoate, omethoate, avermectin, oxythioquinox), and herbicides (gliphosphate, paraquat) are commonly employed. Several of these are, or can be, extremely toxic for zooplankton, mollusks, insects, and/or fish (Pesticide Action Network of North America, online database). Their presence in the Laguna de Cuyutlán food web has not been investigated, but we have seen only one deformed egg, and no ill-calcified ones, suggesting that at the time there was not a 
serious problem for waterbirds. Also as part of farming practices, fertilizers are used widely, and maximum values of phosphates in the lagoon coincide with the rainy season (SosaÁvalos 1988). Supplies of agricultural nutrients could contribute to phytoplankton blooms or to local, ephemeral eutrophication in the lagoon, but this has not been explored.

As late as the 1970s the city of Manzanillo had three discharges of raw sewage into the northwestern end of the lagoon and lagoonshore inhabitants discarded their offal directly into it (Treviño-Acuña 1980). Fecal coliform bacteria and streptococci were documented in 1981 (Ortiz-L. 1983). By 1992 the city's sewage management system had been enlarged (Salinas et al. 1992), but in 1996-1997 coliform counts were again at unacceptable levels near human inhabited shores (Buenrostro-Mariscal 1999). Urban derived supplies of nutrients could also cause phytoplankton blooms or local eutriphication in Basin I and a small section of Basin II.

In the late 1970s a petroleum-fueled thermoelectric facility began operating in Basin I. It constantly discharges a heavy smoke into the air and is allegedly the second most polluting energy-plant in Mexico (Buchanan 2004), although it is not known whether the gases expelled from the plant have an impact on the lacustrine system. Associated with this plant, on 10 December 1984 there was an oil spillage (Muñoz-Cabrera et al. 1987). Its environmental consequences apparently were not evaluated, although they were probably confined to Basin I.

A nearby soft-drink bottling plant has an allowance to discharge waste waters into the lagoon (Castro-Soto 2005), although it has never used it (Alejandro Sánchez pers. comm.). However, it reflects how federal water authorities have perceived Laguna Cuyutlán.

On the other hand, despite strong local opposition, a re-gasification plant is being constructed in Basin II, near the thermoelectric plant. One of the arguments used to support it is that it is needed to convert the thermoelectric plant so that it reduces its polluting emissions.
Other reasons seemingly have to do with a general policy by the Mexican government to promote use of natural gas as a source of energy.

The port of Manzanillo handles $90 \%$ of all container traffic of Mexico's Pacific coast, and such traffic is expected to grow. To increase its capacity, the port will enlarge to the north, but for future growth the Mexican Ministry of Communication and Transport has planned to create an additional port in the northeastern part of Basin II, with up to 80 docking spaces and 20 kilometers of industrial development along the shore (H. Mora-Gómez, Manzanillo's Port Administrator, press release by the Secretaría de Comunicaciones y Transportes, 23 November 2005). Both the re-gasification plant and a new port would require the opening of a larger connection with the sea and dredging of a large and deep navigation channel inside the lagoon. As a result, changes in water levels and circulation, including stronger tidal influences and, perhaps, ship-induced waves, might occur. After its opening in 2000, canal Tepalcates silted rapidly.

\section{DISCUSSION}

Waterbirds are dependent on localized, limited habitat, and are, therefore, very vulnerable. Indeed, throughout the continent they face many conservation threats due to the deterioration or loss of their habitat (Kushlan et al. 2002). Several of the threats that waterbirds experience elsewhere are also present in Laguna Cuyutlán, but have not been taken into account by government agencies, or investigated in detail.

Little is known on the natural sources of waterbird mortality in Cuyutlán. In 2005 a black skimmer colony exhibited signs of egg predation by racoon (Procyon lotor). Also, we have seen more crocodile (Crocodylus acutus) tracks on an islet with a large royal tern colony than at other such islets with no waterbird colonies, or with only laughing gulls nesting. Crocodiles eat domestic fowl readily, and they would likely take also ground-nesting waterbird chicks when they can. Crocodile population in 
the lagoon is at low numbers compared with historical accounts (in the early $20^{\text {th }}$ century Laguna Cuyutlán was known also as Laguna de los Caimanes), and their predation upon waterbird chicks is probably not of conservation concern. Lastly, given the large local population of laughing gulls nesting in Laguna Cuyutlán, and their predatory capacity, it would be rather surprising if they didn't predate upon eggs and chicks of other ground-nesting waterbirds.

Laguna Cuyutlán is in the hurricane track, and hurricanes can temporarily alter the conditions inside the lagoon, and, hence, the waterbirds. During the worst hurricane on record to hit the west coast of Mexico (Beulah, October 1959), water was said to have risen $1.8 \mathrm{~m}$ above their previous level inside the lagoon (Saunders and Saunders 1981). Although the hurricane season starts at the end of the ground-nesting waterbird breeding season, it might affect late nesters, and food availability for these birds and their chicks as well as for waders. By affecting water levels in the lagoon, hurricanes can influence winter usage of waterbirds and, possibly, the ground nesters of the next season, if water level remains high in the Spring.

On their part, tsunamis can cause sea water to enter the lagoon over the sand bar that separates it from the sea. This happened in 1816 or 1818 (the information is imprecise), and on 22 June 1932 (Ewald 1985, Salazar-Cárdenas 1989), when the town of Cuyutlán was virtually swept away. The effects of a tsunami during the breeding season could be severe for the waterbirds, albeit temporary.

At least one red tide has been documented inside Laguna Cuyutlán, and blamed for a fish die-off through either intoxication or oxygen depletion. It developed in April 1982 and was caused by Gonyaulax sp. and Gymnodinium sp. (Baltierra-Rodríguez et al. 1983). Red tides could be a natural feature of this lagoon, but could also have been caused by external supplies of nutrients from fertilizers or by a reduction of zooplankton due to agricultural pesticides. No data to evaluate any of the possibilities is available.

In 2006 a large part of the lagoon dried, allegedly because of the closure by silting of
Canal Tepalcates, and because the thermoelectric plant allegedly draws more water than that supplied through Canal Ventanas. We did not survey the breeding waterbirds in 2006, but nesting was apparently depressed (J.L. Ramírez pers. comm.). When Canal Tepalcates was reopened, the lagoon filled briefly with seawater, but the works were suspended due to hurricaneinduced damage. Abundant rains raised the water level even more, and in October levels were extremely high, and might have prevented foraging by shorebirds, but could have been good for waterfowl.

The two productive activities in Laguna de Cuyutlán, fishing and salt production, do not seem to pose a direct threat to the birds on which we report. Areas used by birds, both to breed and to feed, are too shallow for most fishing skiffs used locally. Also, the fish captured by fishermen are larger than what most birds feed upon. The catch is unlikely to be large enough to affect the food availability for the birds. Production of salt does not seem to interfere with the waterbirds, except for the area directly occupied by the salt pans, some of which could have been suitable for the nesting of snowy and Wilson's plovers and least terns. Surfaces devoted to salt production vary between years, and could render the entire area of documented Snowy Plover nesting unsuitable during some years. On the other hand, the salt pans used to provide habitat for invertebrates which were fed upon by some shorebird species. However, currently salt pans are lined with plastic, almost eliminating this benefit.

Most colonies of ground-nesting waterbirds are not reachable by the means available to most people, and are largely spared from human visits. Even those that are reachable apparently do not receive human visitors either. Mogote Prieto and the islands in Basin II can be reached, but not easily, depending on water level in the lagoon, and people sometimes get there. However, it is our appreciation that people do not seem to interfere much with the nesting birds. If water levels are increased, access might be easier, leading to a higher visitation rate and a higher potential for impact, 
supposing that mangrove-nesting birds are still able to forage adequately in the lagoon and continue breeding there.

Probably the most serious threats to waterbirds in Laguna Cuyutlán is a long term modification of the water levels, especially increases. Since the lagoon cannot expand shore-wise, or would be prevented from doing so, the shallow waters might be lost. The islets and saltflats on which Charadriiformes nest could disappear, and the resulting deeper waters might not provide an appropriate feeding habitat for most wading and shorebirds. The permanent opening of an artificial channel might cause such conditions, and ship-induced waves likely would worsen them. This might be the consequence of the planned development for the lagoon.

Pesticides, urban sewage, and any other exogenous substances reaching the lagoon are all potential threats to the waterbirds that use Laguna Cuyutlán, as well as to other biotic components of the system, but we lack information on any such effects. If there is any relationship between fertilizer-derived nutrient supplies to the lagoon and phytoplankton blooms, this might be of concern for bird conservation, as well as for the local fishery.

Currently the main concern of academics, fishermen, and government officers is the connection between the lagoon and the sea, and are all in favor of it. Conversely, we think that such a connection should be evaluated critically as to its overall effects on biodiversity, and that special efforts should be made to understand the role of fresh water supplies to Laguna Cuyutlán (Mellink et al. accepted-b).

\section{CONCLUSIONS AND RECOMMENDATIONS}

Notwhistanding our limited knowledge, Laguna Cuyutlán is clearly important for waterbirds. Given the paucity of data, it is not possible to speculate on the repercussions of "losing" Laguna Cuyutlán, but it seems likely that it would complicate conservation efforts, especially since other sites along western Mexico are also being lost or degraded.
The data available on waterbirds suggests that Laguna Cuyutlán should be considered an AICA, and protected from habitat alterations, either physical or chemical.

The worst threats for the maintenance of the biological integrity of the lagoon come from the contempt for biological conservation by many of those involved with decisions about the area. Examples of this are the allowance for using the lagoon to discard waste waters and of raising tilapia. Mexico's overall government plans during the 2000-2006 presidential term were focused on economic development and globalization, with an apparent neglect for the conservation of the biological and cultural heritages. The current government (2006-2012) will apparently maintain the same focus. It is within this scenario that conservation actions must be proposed. Despite the threats, real and potential, lurking at Laguna de Cuyutlán, we think that we must, and it is possible, to conserve an important part of its role in the maintenance of biodiversity. To this end, we recommend that:

1) Laguna Cuyutlán be nominated as an Area de importancia para la conservación de las aves (Important Bird Area).

2) The re-gasification plant and the future port development at least include a levee to prevent alterations in water level in as large a section of the lagoon as possible, including the totality of Basins III and IV.

3) Supply of exogenous chemicals and waste products be prevented and monitored, and agricultural use of pesticides be monitored as to compliance with environmentally safe procedures.

4) The supposed benefits from water interchange through artificial channels between the lagoon and the sea be analyzed carefully and contrasted with its potential impact on biological conservation.

5) Biodiversity of the lagoon be monitored for several years, and attention be paid to unusually rainy years to assess the role of fresh water supplies to the lagoon.

6) Local inhabitants, especially users of the lagoon, who are aware of some of the 
services provided by the lagoon to them, be involved in any conservation strategy for the area.

\section{ACKNOWLEDGMENTS}

Jorge Luis Ramírez (independent fisherman) provided information on fishing and salt production, and has been our guide and boater to the central part of Laguna Cuyutlán. Additional information was generously provided by Jesús Delgado-Virgen and Telésforo Ramírez-Montes (Cooperativa Sal Real de Colima), Jorge Aguilar Torres (fisherman), Víctor Manuel MedinaUrrutia (Instituto Nacional de Investigaciones Forestales Agrícolas y Pecuarias, Tecomán), Mary Cruz Rivera and Rafael Robles (El Tortugario, Cuyutlán), and Alejandro Sánchez (Tecomán). Enrique González Lagunas kindly assisted us at the Archivo General de la Nación (México). Editorial comments were provided by Leticia Hernández-López, Ernesto Franco, and Jaime Luévano. We extend our appreciation to all of them. Funding was provided by the Centro de Investigación Científica y de Educación Superior de Ensenada (CICESE) and the Universidad de Guadalajara (UdG).

\section{RESUMEN}

Laguna Cuyutlán, el único humedal grande a lo largo de $1150 \mathrm{~km}$ del Pacífico mexicano, no ha sido considerado un ecosistema natural importante para la conservación de aves acuáticas. Cuando menos 25 especies de aves acuáticas anidan ahí, y al menos 61 especies de aves acuáticas la usan fuera de la temporada reproductiva. Esta laguna ha sufrido varias modificaciones estructurales, y el aporte de agua dulce ha disminuido, sin que se conozcan sus consecuencias. La extracción de sal y la pesca artesanal, las principales actividades económicas, no parecen ser riesgo para las aves acuáticas. Entre los riesgos potenciales, están las aguas negras cerca de zonas urbanas y los plaguicidas de zonas agrícolas colindantes. Aparentemente, el riesgo más serio deriva del desarrollo marítimo asociado con una planta regasificadora a construirse pronto, y del desarrollo portuario futuro, que podrían incrementar los niveles de agua en la laguna y alterar los hábitats de las aves acuáticas. Recomendamos que: el área se declare como AICA; el desarrollo futuro incluya un dique para prevenir alteraciones en el nivel del agua en el resto de la laguna; el aporte de sustancias agroquímicas y aguas negras se monitoree; se reevalúen los supuestos beneficios del intercambio de agua entre la laguna y el mar por medio de canales artificiales; y se investigue científicamente los aportes de agua dulce a la laguna.

Palabras clave: Laguna Cuyutlán, Colima, México, aves acuáticas, biología de la conservación, desarrollo portuario, contaminación acuática.

\section{REFERENCES}

Anonymous. 1850. Ensayo estadístico sobre el Territorio de Colima. Bol. Inst. Nal. Geog. Estad. 1:244-299.

Arizmendi, M.C. \& L. Márquez-Valdelamar. 2000. Áreas de importancia para la conservación de las aves en México. Consejo Internacional para la Preservación de las Aves, Sección México, México, D.F., México.

Ascencio-Borondón, F., C. Solis-Gil \& L. Coba-Cetina. 1987. Investigación biológico - pesquera del recurso camarón Penaeus californiensis (Holmes) en la Laguna de Cuyutlán, Colima, México. Resúm. Cong. Nal. Oceanog. 7:33.

Baltierra-Rodriguez, J.L., G. Cluyas-Millan \& J.C. ChávezComparan. 1983. La marea roja de abril de, 1982 en la laguna de Cuyutlán, Colima, México. Cien. Mar. 9:35-39.

Buchanan, R. 2004. Mundo energético: Pleito entre hermanos. La Jornada, 29 November; weekly supplement La Jornada Económica 33:8.

Buenrostro-Mariscal, A.E. 1999. Evaluación y diagnóstico de la calidad del agua en la Laguna de Cuyutlán, Colima 1996-1997. B.Sc. thesis. Universidad de Colima. Colima, Col., México.

Cabral-Solís, E.G. 1999. Estudio sobre el crecimiento y aspectos reproductivos de la lebrancha Mugil curema (Cuvier y Valenciennes, 1836), en la Laguna de Coyutlán, Colima. M.Sc. thesis. Universidad de Colima. Colima, Col., México.

Cabral-Solis, E.G. \& E. Espino-Barr. 2004. Distribución y abundancia espacio-temporal de los peces en la Laguna de Cuyutlán, Colima, México. Oceanides 19:19-27.

Cabral-Solís, E.G., E. Espino-Barr, R. Macías-Zamora, M. Puente-Gómez \& A. García-Boa. 2006a. variación del índice de diversidad, riqueza y equitatividad en la Laguna de Cuyutlán, Colima, de, 1999 a, 2004. Resúm. Ext. Cong. Nal. Oceanog. (México) 14:580-583.

Cabral-Solis, E.G., H. Santana-Hernández, E. EspinoBarr, A. García-Boa, M. Puente-Gómez \& L.D. Corrales-Pacheco. 2006b. Análisis comparativo de 
la captura, el esfuerzo y la captura por unidad de esfuerzo en la Laguna de Cuyutlán, Colima durante el período, 2000-2004. Resúm. Ext. Cong. Nal. Oceanog. (México) 14:584-587.

Canonico, G.C., A. Arthington, J.K. McCrary \& M.L. Thieme. 2005. The effects of introduced tilapias on native biodiversity. Aquatic conservation: Mar. Freshw. Ecosyst. 15:463-483.

Castro-Soto, G. 2005. La Coca-cola en México: El agua tiembla. Part 10 of Coca-cola: la historia negra de las aguas negras. Boletín Chiapas al Día \# 445. Centro de Investigaciones Económicas y Políticas Comunitarias (CIEPAC, www.ciepac.org).

Contreras, F. 1985. Las lagunas costeras mexicanas. Centro de Ecodesarrollo, México, D.F., México.

de Lasaga, D. 1940. Descripción geográfica del partido de Colima. Bol. Archiv. Gral. Nación 11:487-501 (written in 1793).

Evans, A.S. 1871. Our sister republic: a gala trip through tropical Mexico in 1869-1870. Columbian Book, Hartford, Connecticut, EEUU.

Ewald, U. 1985. The Mexican salt industry, 1560-1980; a study in change. Stuttgart, New York, EEUU.

Geiger, J.L. 1874. A peep at Mexico: Narrative of a journey across the Republic from the pacific to the Gulf in December 1873 and January 1874. Trübner \& Co, London, England.

Hernández-Vázquez, S. \& E. Mellink. 2001. Coastal waterbirds of El Chorro and Majahuas, Jalisco, México, during the non-breeding season 1995-1996. Rev. Biol. Trop. 49:359-367.

Howell, S.N.G. 1994. Additional information on the birds of Colima and adjacent Jalisco, Mexico. Euphonia $3: 33-54$.

Howell, S.N.G. 1999. A bird-finding guide to Mexico. Cornell University Press. Ithaca, New York, EEUU.

Howell, S.N.G. \& S. Webb. 1995. A guide to the birds of Mexico and northern Central America. Oxford University Press, New York, EEUU.

Hugues-Dit-Ciles, E.K. 2000. Developing a sustainable community-based aquaculture plan for the Lagoon of Cuyutlan through a public awareness and involvement process. Coastal Manag. 28:365-383.

INEGI. 1996. Atlas agropecuario; Colima (VII Censo Agropecuario, 1991). Instituto Nacional de Estadística Geografía e Informática, Aguascalientes, Ags., México.
Instituto Oceanográfico de Manzanillo. 1984. Evaluación de los recursos ecológicos del estado de Colima. Manzanillo, Col., México.

Jiménez, G.A. 1992. La utilización de las zonas de marismas en la acuicultura. Una alternativa de uso y manejo para los ecosistemas de la costa tropical del Pacífico mexicano. Resúm. Cong. Nal. Oceanog. 9:77.

Knoder, C.E., P.D. Plaza \& A. Sprunt IV. 1980. Status and distribution of the Jabiru Stork and other water birds in western Mexico. P. 58-127. In P.P. Schaeffer, and S.M. Ehlers (eds). Proceedings of the National Audubon Society's Symposium on the Birds of Mexico; their ecology and conservation. Western Education Center. Tiburon, Calif., EEUU.

Kramer, G.W. \& R. Migoya. 1989. The Pacific coast of Mexico. P. 507-528. In L.M. Smith, R.L. Pederson, and R.M. Kaminski (eds). Habitat management for migrating and wintering waterfowl in North America. Texas Tech University, Lubbock, EEUU.

Kushlan, J.A., et al. 2002. The North American Waterbird Conservation Plan. Waterbird conservation for the Americas. Washington, D.C., EEUU.

Leopold, A.S. 1977. Fauna silvestre de México; aves y mamíferos de caza, 2nd ed. Instituto Mexicano de los Recursos Naturales Renovables, México, D.F. México.

Marmolejo-Rodríguez, A.J. 1989. Obtención de sales de potasio y litio a partir del proceso de extracción de bromo y sales de magnesio de las salinas de la Laguna de Cuyutlán, Colima. B.Sc. thesis. Universidad de Colima, Manzanillo, Col., México.

Mellink, E. \& G. de la Riva. 2005. Non-breeding Waterbirds at Laguna de Cuyutlán and associated wetlands, Colima, Mexico. J. Field Ornith. 76:158-167.

Mellink, E. \& M.E. Riojas-López. 2005. New breeding localities for the Snowy Plover in western Mexico. W. Birds 36:141-143.

2006. Nesting of Forster's Tern in a tropical coastal lagoon, Cuyutlán, Colima, Mexico. W. Birds 37:45-47.

2007. Modificaciones estructurales artificiales de Laguna Cuyutlán, Colima, México. Rev. Geog. 142. In press.

. 2008. Non-Laridae waterbirds breeding in Cuyutlán, Colima, Mexico. Rev. Biol. Trop. 56:391-397. In press.

Mellink, E., E. Palacios \& E. Amador. 2007. Colonies of Four Species of Terns and the Black Skimmer in Western México. Waterbirds 30:358-366. 
Mellink, E., M. Riojas-López, \& J. Luévano. Accepted-a. Coastal breeding locations of seven Charadriiformes from Jalisco to Guerrero, southern Mexico. Waterbirds.

Mellink, E., M. Riojas-López, J. Luévano \& J. Wheeler. Accepted-b. Historic changes in mid-winter use of Laguna Cuyutlán, Colima, Mexico, by waterfowl. Neotrop. Ornithol.

Mena-Herrera, A. 1979. Contribución al conocimiento de los factores que influyen en la productividad de la Laguna de Cuyutlán, Col. con énfasis en el camarón. B.Sc. thesis. Universidad Nacional Autónoma de México, México, D.F., México.

Miller, A.H., H. Friedmann, L. Griscom \& R.T. Moore. 1957. Distributional check-list of the birds of México, part two. Pacific Coast Avifauna 33.

Morrison, R.I.G., R.K. Ross \& S. Torres-M. 1992. Aerial surveys of neartic shorebirds wintering in Mexico: Some preliminary results. Canadian Wildlife Service Progress Notes 201:1-11.

Morrison, R.I.G., R.K. Ross \& J. Guzman-P. 1994. Aerial Surveys of Nearctic Shorebirds Wintering in Mexico: Preliminary Results of Surveys of the southern half of the Pacific Coast, States of Chiapas to Sinaloa. Canadian Wildlife Service Progress Notes 209:1-21.

Muñoz-Cabrera, L., A. Peñaloza-Millán \& F. AscencioBorondón. 1987. Evaluación de la contaminación por hidrocarburos derivados del petróleo en la laguna de Cuyutlán, Colima, México. Resúm. Cong. Nal. Oceanog. 7:392.

Myers, J.P. 1983. Conservation of migrating shorebirds: Staging areas, geographic bottlenecks, and regional movements. Am. Birds 37:23-25.

Myers, J.P. et al. 1987. Conservation strategy for migratory species. Am. Sci. 75:18-26.

Palacios, E. \& E. Mellink. 2007. The colonies of vanRossem's Gull-billed Tern (Gelochelidon nilotica vanrossemi) in México. Waterbirds 30:214-222.

Ortiz-L, J.H. 1983. Evaluación de los niveles microbiológicos de coliformes fecales y estreptococos alcanzados en la laguna de Cuyutlán, Manzanillo, Colima, México. B.Sc. thesis. Escuela Nacional de Estudios Profesionales-Iztacala, Universidad Nacional Autónoma de México, México, D.F., México.

Pérez-Arteaga, A., K.J. Gaston \& M. Kershaw. 2002. Undesignated sites in Mexico qualifying as wetlands of international importance. Biol. Cons. 107:47-54.

Pérez Ponce de León, M.J. 1979. Descripción del distrito de Colima y del corregimiento agregado de San Miguel de Xilotlán. 1776-1777. P. 176-207. In Documentos para la historia del estado de Colima. Siglos XVIXIX, Colección Peña Colorada, Col., México.

Salazar-Cárdenas, J. 1989. El maremoto de Cuyutlán, 1932, Sociedad Colimense de Estudios Históricos, Colima, Col., México.

Saunders, G.B. \& D.C. Saunders. 1981. Waterfowl and their wintering grounds in México, 1937-64. Fish and Wildlife Service Resource Publication 138.

Schaldach, W.J. 1963. The avifauna of Colima and adjacent Jalisco, Mexico. Proc. W. Found. Verteb. Zool. 1:1-100.

Scott, D.A. \& M. Carbonell. 1986. A Directory of neotropical wetlands, International Union for Conservation of Nature and Natural Resources and International Waterfowl Research Bureau, Cambridge, U.K.

Sosa, A.H. 1939. Exploración forestal en el litoral del estado de Colima. Bol. Depto. For. Caza y Pesca 14:183-207.

Sosa-Ávalos, R. 1988. Distribución de las comunidades fitoplanctónicas y su relación con los parámetros fisico-químicos durante un ciclo anual en la Laguna de Cuyutlán, Colima. B.Sc. thesis. Universidad de Colima. Colima, Col., México.

Treviño-Acuña, L. 1980. Algunas consideraciones sobre el impacto ecológico debido a la construcción de la planta termoeléctrica Manzanillo en la Laguna de Cuyutlán, Colima, México. B.Sc. thesis. Universidad Autónoma de Baja California, Ensenada, B.C., México. 